depends on the diet of the pig. More lately it has been found that mild-cured or tank-cured bacon, frozen at $-35^{\circ} \mathrm{C}$. and stored at $-10^{\circ} \mathrm{C}$. or $-15^{\circ} \mathrm{C}$., after slow thawing, and smoking in the case of the latter, tasted for the greater part like ordinary bacon after cooking, but in each case slight rancidity had developed in small areas of the fat. Work has also been carried out on the swelling of gelatin and pork muscle in solutions of sodium chloride.

The Torry Fish Research Station acquired the steam-drifter City of Edinburgh during the year. C. A. Reay has carried out further experiments on the freezing and cold storage of haddock. Under certain conditions an irreversible change in the muscle occurs which may not be very obvious on thawing but is evident after curing, since the glossy pellicle of the surface is absent and the tissue is friable, inelastic, and opaque instead of elastic and translucent. The rate of change is slowest at $29^{\circ}-25^{\circ} \mathrm{F}$. and $-9^{\circ}$ to $-13^{\circ} \mathrm{F}$., and quicker at the intermediate tempera. tures; at the higher, bacterial growth occurs, the lower involves greater expense in refrigeration.

Research work on fruit and vegetables has been continued. J. Barker has found that cyanide at first accelerates the respiration of the potato instead of inhibiting it as in the case of many animal tissues. The effect appears to be due to an activation of the starch-hydrolysing mechanism, so that more respirable material is available : later inactivation occurs. A. S. Horne has found that East Malling apples, which have a reputation for good keeping qualities, owe their freedom from wastage to absence of infection in the orchard: when infected they are less resistant than fruit from other areas. Resistance to fungal attack depends in part on the acid content of the apples; which decreases with age.

\title{
The Idu (Japan) Earthquake of Nov. 26, I930.
}

CINCE the great disaster of 1923, Japan has been visited by three destructive earthquakes, in the Tazima province on May 23, 1925, when 428 lives were lost; in the adjoining Tango province on March 7, 1927, when 3017 persons were killed, and in the Idu peninsula on Nov. 26, 1930. Prof. A. Imamura

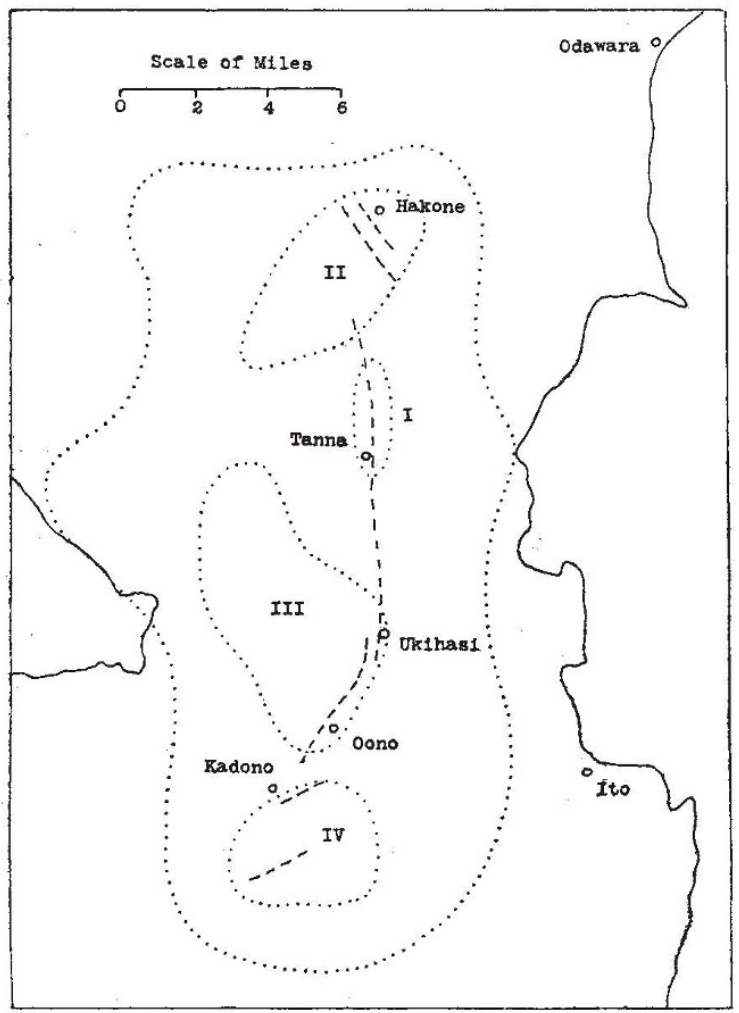

FIG. 1.

has written two interesting papers on the last-named earthquake while a valuable memoir has recently been contributed by Mr. S. I. Kunitomi of the Central Meteorological Observatory.*

According to Mr. Kunitomi, the earthquake was felt over a land-area of 133,000 sq. miles, including

* Tokyo Imp. Acad. Proc., vol. 6, pp. 419-422; 1930, and Japan. Jour. Astr. Geoph., vol. 8, pp. 51-65; 1931. Tokyo Geoph. Mag., vol. 4, pp. 73-102; 1931 .

No. 3230, Vor. 128] the greater part of Japan. The series of Ito earth. quakes, more than 4000 in number, closed at the end of May (NATURE, vol. 126, pp. 326, 971). Then followed a pause of about five months until Nov. 7, when a slight earthquake occurred with its epicentre near the Tanna basin. Every day after this, the foreshocks of the Idu earthquake increased in number until, on Nov. 25, 734 shocks were recorded at the Misima Observatory near the north end of the penin. sula. Up to 4 A.M. on Nov. 26 , the total number of fore-shocks was 2165 , of which 184 were felt at the observatory. Mr. Kunitomi's map representing the distribution of the fore-shock and after-shock epicentres shows that the former were as a rule clustered along the Tanna fault, while the latter were widely scattered over the epicentral region and especially at the bases of Mounts Huzi, Asitake, and Hakone, and off Cape Ooze.

One of the most useful sections of Mr. Kunitomi's paper is that which deals with the origin of the Ito and Idu earthquakes. He has studied the distribution of the directions of initial motion in the Idu earthquake and the stronger Ito earthquakes, especially that of March 22. In all of these earthquakes the distribution is the same, and implies in each a horizontal movement of the crust-blocks along a N.N.W. and S.S.E. line, or nearly along the course of the Tanna fault, the eastern block moving to the north and the western to the south.

The Idu peninsula lies on the west side of Sagami Bay, the bed of which and the surrounding shores formed the epicentral area of the Kwanto earthquake of Sept. 1, 1923. Prof. Imamura points out that there have been three epochs of seismic activity in this region, in 818,1703 and 1923 , and that the first and third were followed, after 23 and 7 years respectively, by destructive earthquakes in the Idu peninsula. The recent Idu earthquake may thus, he suggests, be regarded as an after-shock of the earthquake of 1923 .

The earthquake occurred on Nov, 26, at $4 \mathrm{~h} .3 \mathrm{~m}$. A.M. (Nov. 25,7 h. 3 m. P.M., G.M.T.). In a sketchmap, the essential features of which are here reproduced (Fig. 1), the broken lines represent the faults along which dislocations occurred during the earthquake, the outer dotted line bounds the area in which at least I per cent of the houses collapsed, the inner dotted lines I-IV, the areas in which the percentage was not less than 25 . It was in the areas II-IV that the greatest losses of life and property occurred, 259 persons being killed and 2142 houses destroyed.

Of the faults that appeared during the earthquake, four are especially noteworthy. (i) The Tanna fault 
crosses the Tanna tunnel at right angles, about 500 feet below the surface. In the tunnel itself, the crust on the west side was shifted $7 \mathrm{ft} .10 \mathrm{in}$. to the south and $2 \mathrm{ft} .0 \mathrm{in}$. downwards relatively to that on the east side ; though, at the surface, the dislocation was much less marked. (ii) The northern or Hakone fault, trending north-west, may be a segment of the Tanna fault. (iii) The Oona fault begins near Ukihasi and runs $\mathrm{S}$. $30^{\circ} \mathrm{W}$., with a relative southward shift of the west side amounting in one place to $3 \mathrm{ft} .3 \mathrm{in}$. (iv) The southern segment of the latter fault, or Kadono fault, trending $\mathrm{S} .70^{\circ} \mathrm{W}$., with relative shift of the west side of $4 \mathrm{ft} .3 \mathrm{in}$. to the south and $1 \mathrm{ft} .8 \mathrm{in}$. upwards.

From a study of the seismograms obtained at Tokyo, Prof. Imamura distinguishes four series of waves coming from as many different origins, that are probably represented by the areas I-IV in the accom. panying map. The movement of the whole blocksystem started north of Ukihasi (in lat. $35^{\circ} 2^{\prime} \mathrm{N}$., long. $\left.139^{\circ} 0^{\prime} \mathrm{E}.\right)$, passed northwards with comparative quietness along the Tanna fault, and southwards, with sharp destructive shocks caused by the displacements of the three blocks II, III, and IV. The crust on the west side of the fault-system was shifted relatively southwards, the whole movement coming to an end after the lapse of about 10 seconds. The stress causing this block-movement probably acted in the same way as that in the great Kwanto earthquake of 1923 ; in other words, the recent Idu earthquake was an after-shock of the Kwanto earthquake.

\section{Davison.}

\section{The National Radio Exhibition.}

THE National Radio Exhibition, which was opened 1 at Olympia on Sept. 18, occupies a floor space three times as large as last year and is now the largest radio exhibition in the world. The exhibition is organised by the British Radio Manufacturers' Association, and is arranged in such a well-planned manner that it cannot fail to be of interest to all broadcast listeners, whether technically minded or not. This exhibition definitely supports the idea which was be. coming evident last year, that the radio manufacturing industry has passed through its somewhat uncertain experimental stage to that of steady development along trustworthy and well-established lines. The modern commercial radio receiver compared with its prototype of a year or two ago, which resembled an ill-assorted collection of components wired together in a box, is built somewhat on the lines of a car chassis.

Apart from the progress made in the design of receivers based on well-established principles, two recent developments are indicated in the exhibition. The first is an attempt to improve the selectivity obtain. able in reception without any appreciable sacrifice of the quality of reproduction. More than one method of reaching this objective is being investigated, and it is possible that the results obtained may to some extent alleviate the interference difficulties which sometimes arise when transmitting stations are in too close proximity to one another, both in a geographical sense and from the point of view of their operating frequencies. The second and perhaps more recent novelty in Great Britain is the introduction of the 'variable-mu' valve, that is, of a valve in which the action of the grid in controlling the anode current varies along the axis of the electrode system, usually as a result of a variation in pitch of the turns of the grid. Such a valve, having a variable amplification factor according to the actual conditions under which it is operating, provides a means of avoiding certain distortion effects encountered in the normal type of screen-grid valve. A means of overcoming the effects of variation of the incoming signal due to fading and other causes is also provided by the new valve, which may be operated under conditions securing automatic volume control in the radio-frequency portion of the set.

A prominent exhibit is that of the British Broadcasting Corporation, which includes a large map of the British Isles showing the density of population in relation to the broadcasting stations. A study of the map reveals that the B.B.C. stations are placed in the most advantageous positions to secure that the great majority of the population are within the service area of one or more stations. Apparatus is also installed on the B.B.C. stand to supply programmes to all loud-speakers operating in the exhibition.

For the rest, the exhibition shows the great range of modern receiving sets which are now available to suit all tastes and length of purse. The great modern tendency is to make the receiver a self-contained unit, including the loud-speaker, and ready for connexion to the electric supply mains. The larger and more expensive models contain also an electrically operated gramophone, and in some cases these now embody automatic record-changing mechanism by means of which half an hour's continuous gramophone music can be obtained without any attention. The more successful of the portable receivers remain in a somewhat improved form, while battery-operated models are still produced for those to whom an electric supply is not available. Altogether it may be said that the receivers show a marked improvement in design and performance over those exhibited last year, while the selling prices are in most cases appreciably lower.

\section{Birthdays and Research Centres.}

Sept. 28, 1873.-Prof. J. L. Coolidge, professor of mathematics in Harvard University.

I am at present engaged on a history of geometrical methods. This is a long work that will cover many years.

A problem to which attention might usefully be given is the situation of the singular points of a rational plane algebraic curve.

Sept. 28, 1889.-Prof. H. MUNRo Fox, professor of zoology in the University of Birmingham.

Protoplasm contains a considerable number of elements, some of them present only in traces. Of these, some may be of considerable functional importance. During the last two years, in collaboration with Mr. H. Ramage, I have been making a quantitative spectrographic study of the presence of traces of elements in the tissues of a wide variety of animals.

Some years ago I carried out a physico-chemical investigation of chlorocruorin, a green blood pigment present in certain polychæte worms. Chlorocruorin turned out to be the only known substance having a chemical structure closely similar to hæmoglobin. By its resemblances and differences it throws light on the nature of hæmoglobin. At the same time chlorocruorin has a number of peculiarities. I am at present studying the blood circulation, metabolism, and mode of life of the animals possessing chlorocruorin, with the view of elucidating the functional rôle of this respiratory pigment.

Oct. 2, 1875 -- Prof. A. W. Conway, F.R.S., professor of mathematical physics, University College, Dublin.

In conjunction with Prof. M'Connell, of Trinity College, Dublin, vol. 2 of Hamilton's "Mathematical 